\title{
Women's Oppression and Politics of Female Reproductive Health in the Indian Subcontinent
}

\author{
Sreerupa Sengupta* \\ Department of English, Auburn University, USA
}

*Corresponding author: Sreerupa Sengupta, Department of English, Auburn University, Alabama, USA.

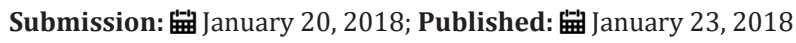

\section{Opinion}

Women in the Indian subcontinent, which consists of primarily three South Asian nations India, Pakistan, and Bangladesh, suffer maximum exploitation because men take undue advantage of women's reproductive labor to the point that women lose their right to their bodies, sexuality, and personhood. Women in this region of the world are often denied the joy and pride culturally attached to motherhood because their pregnancy does not get validation either from their families/communities or from their male partner. Ironically, the interest of a husband or a partner does not always match with the interest of a society. For example, although subcontinental cultures value bearing a healthy male offspring, women bearing male children may fail to evade exploitation because their husbands or partners disapprove the legitimacy of their pregnancy. Women are victimized by this clash of individual and collective male interests of patriarchal societies. A maternal body is oppressed due to the situational implication of a woman's pregnancy. This implication varies from woman to woman depending on the contextual demands of their bodies. In order to understand women's oppression in countries like India, Pakistan, and Bangladesh, we need to situate the discussion about pregnancy, abortion, and sterility of women within the religionhistory-culture nexus that affects a woman's decision to become pregnant or continue her pregnancy in a safe way. Therefore, women's reproductive health crucially determines their position as subjects capable of making decisions about their lives and bodies. A woman's attachment to her fetus and her maternal body influences her identity. A pregnant woman or a mother's identity can experience severe threat when external agents, including socio-economic, cultural, or patriarchal interests interfere with this attachment. The outcome of this interference can be dangerous both for the health of a mother and the overall wellbeing of a social unit [1-3].

Corporeal feminist theorist Elizabeth Grosz [4] in "Notes towards Corporeal Feminism" asserts that women's bodies are "often used to reduce [them] to a pseudo-evolutionary function in the reproduction of the species, which supposedly acts as a compensation for women's social powerlessness" ("Notes towards
Corporeal Feminism" 3) [5]. Grosz's observation is specifically relevant in the context of the Indian subcontinent where the age old tradition, religion, and nationalist politics prioritize women's prime role as mothers and their divine maternal power capable of destroying evil forces like colonialism and imperialism. Unfortunately, this idealization hardly translates to real life situations where women are virtually powerless in countering their culturally-sanctioned and socially-accepted inferiority. Reproduction is often considered as a crucial determinant of a woman's acceptability in the subcontinental culture because it is an obligation that they must conform to in order to retain their positions in a family, community, or society.

Religion in the Indian subcontinent is a highly influential factor in determining the norms of fertility. In ancient India, female fertility and its regulation through legitimate impregnation and conception of male offspring remained an important aspect of social life. In her article "Motherhood in Ancient India," Sukumari Bhattacharya [2] refers to Hindu scriptures like Rgveda and Upanishada that highlight motherhood as a woman's most important duty (44). After the wedding, a newly-married couple used to pray for a male child who was considered to be "essential for the continuation of the line, and for the preservation and multiplication of wealth" (Bhattacharya 45). Bhattacharya refers to the Hindu custom of feeding the wives different kinds of food so that they could "conceive different kinds of children-wise male, wise and intelligent female child, etc." (45). Unfortunately, mothers of female children or mothers who died at childbirth could easily be replaced with a new bride (45). Bhattacharya further refers to the Rgveda in order to demonstrate that scriptures control women's fertility and their bodies and expose them to different degrees of oppression or marginalization. Vedic texts pronounce that "a barren woman could be cast away because she was possessed by [...] a negative concept of a spirit that is exceedingly ugly and wholly evil" (46). While the barren woman "could be discarded after ten years, a woman who gives birth to daughters only is discarded after twelve years, and the mother of stillborn children after fifteen years. The husband of a sonless wife should marry again" (47). There are also numerous instances of "imposed pregnancy" where impotent husbands share the wives 
with the sages for male children or with an unlimited number of male guests to get their blessings (48).

Due to the organized control of female sexuality and fertility through religion and patriarchal social structure, "there is a steady decline in a mother's social status as a woman, an independent, moral agent, a social entity, a free sexual partner, a co-responsible partner for child-rearing, and as a parent participating in the decisions regarding the children's development and growth" (64). Numerous goddesses in the Hindu religion and mythology glorify the power of a mother by simultaneously having children and killing demons; however, for real mothers, the power is completely lost in the pains of childbirth, nurturing, and the observance of numerous arduous rituals for the wellbeing of their husbands and male offspring. The divine mother, which is simply an ideology, and the real mother, the imposition of that ideology on women, "belong to diametrically opposite planes. The human mother is within her heavily circumscribed domestic region, with little scope to assert her will [...] [but] the divine mother's will is creative at the cosmic level" (65).

Like Hindu scriptures, the Qur'an, Hadith, and Islamic jurisprudence consider motherhood as a divine duty entrusted by the almighty Allah to women in order to bless their womb. Aliah Schleifer's [6] illuminating study on motherhood and Islam reveals Islam's glorification of a mother through the establishment of her affinity with the martyr [1]. Schleifer refers to exegete Ahmad Ghunaim in this context, who maintains that by "considering the mother [to be] a martyr, Islam places her in the highest of categories with respect to Allah's blessing" [1]. Ghunaim states that Hadith also considers a woman "who dies in childbirth as one of the martyrs" [1]. This view discredits the common misconception that "childbirth is a punishment for "original sin" and establishes childbirth as a means "to face pain and the danger [...] for the sake of Allah" [2]. Further still, marriage is considered in Islam as "a desired state of affairs" and "childbirth is considered the natural outcome of marriage" (Schleifer 51). Pregnancy and nursing are "spiritual acts" and opportunities to "obtain Allah's blessings and rewards" (51). The Hadith also maintains, similarly, that a woman "receives the reward of one who fasts and prays for the sake of Allah" if she "is pregnant by her husband and he is satisfied with her" (53). These references clearly reveal that even though pregnancy is a virtuous act for women, the child should be a product of a legitimate marital bond, and the pregnancy should be attained through sexual satisfaction of the husband. A pregnant woman is entitled to additional blessings if she nurses her baby and "is kept awake by her child at night" (53). Thus, the most important duties of a Muslim woman are "pregnancy, childbirth, nursing, and conscientious rearing of her children," the successful performance of which can help her attain the Paradise (58).

Like religion, nationalist politics and anticolonial struggle in the subcontinent are imbued with the rhetoric of female fertility and the maternal female body. South Asian feminist critic Bishnupriya Ghosh [3] maintains in this context, "Indian nationalist rhetoric always projected the nation as maternal in form" (140). Ghosh refers to Lauren Berlant's discussion of a maternal body which "in its wholeness and promise of plentitude is an integrative national fantasy where the individual reads the promise of political subjecthood" (Berlantqutd, in Ghosh 140). As Ghosh and Berlant's discussion reveal, the conception of precolonial India as a maternal body "raped" by British colonial power during its rule provides "the sons" a political agenda to restore her dignity (Ghosh 141). The "maternal anatomy in [the subcontinental] cultural imaginary" creates the rationale for "ownership [and] possession of the maternal national body"(141). The mother is expected to nurture her sons' dream but cannot embrace it as her own. Therefore, in a nation personified as a mother, real mothers take the backseat because they are more a symbol or signifier of paternalistic or masculine desire than holders of maternal power. The abstract ideology of a pristine motherland and its "spiritual superiority" over western material dominance is imposed on real women of flesh and blood, who are expected to maintain their status as vanguards of indigenous cultural superiority by, to use the words of Partha Chatterjee, "remaining untouched by the material, political, and legal changes of modern India" (Chatterjee qtd. in Ghosh 142). These discussions assert that motherhood was used by the colonized intelligentsia as a convenient tool that would validate their "selfhood and identity" among the western rulers. This validation was perceived not as "a mere victory of traditionalism over the modernizing tendency of the social reform era" but as a "symbol of nationalist aspiration, an excellent ploy to keep women out of privileges, like education and profession [...] and to glorify womanhood only through [women's] reproductive powers" (Bagchi 167).

The image of the mother as a goddess and an emblem of divine power does not help women much, primarily, because women are more preoccupied with the expectations of motherhood set by their male partners or their families than to satisfy their own desires. Thus, the combative image of fierce "Mother India" remains a chimera for women of the subcontinent. The reality of the Indian subcontinent does not allow empowerment and motherhood to coexist within a patriarchal society where motherhood is imposed and fertility is exploited for the glorification of masculinity. Many women who joined the nationalist cause were forced to return to the private spheres and perform their traditional roles once India got its freedom. The socio-economic crisis and religious strife of the newly free nations, India and Pakistan, and eventually, Bangladesh, directly affected women whom the rhetoric of fertility and motherhood place within a vicious cycle of exploitation through forced sacrifices for the sake of their heroic, accomplished, or failed sons.

\section{References}

1. Jashodhara B (2010) Representing Nationalism: Ideology of motherhood in colonial bengal motherhood in India: Glorification without empowerment? In: Maithreyi Krishnaraj, Routledge (Eds.), Representing Nationalism: Ideology of Motherhood in Colonial Bengal Motherhood in India: Glorification without Empowerment? UK, pp. 158-185.

2. Sukumari B (1990) Motherhood in Ancient India. Motherhood in India, pp. 44-72. 
3. Bishnupriya G (1997) Interventions: Feminist dialogues on third world women literature and film. Garland Publishing, USA.

4. Elizabeth G (1994) Volatile Bodies: Towards A Corporeal Feminism. Indiana UP, USA.
5. Elizabeth G (1987) Notes towards Corporeal Feminism. Australian Feminist Studies 2(5): 1-16.

6. Aliah S (1986) Motherhood in Islam. Fons Vitae, Netherlands. 